\title{
KOMUNITAS LEPIDOPTERA DAN PARASITOIDNYA PADA PERTANAMAN MENTIMUN DI BOGOR, SUKABUMI DAN CIANJUR, JAWA BARAT
}

\author{
Evawaty S. Ulina ${ }^{1,3}$, Akhmad Rizali $^{2}$, Pudjianto $^{3}$, Sjafrida Manuwoto $^{3}$, \& Damayanti Buchori ${ }^{3}$ \\ ${ }^{1}$ Balai Pengkajian Teknologi Pertanian Sumatera Utara \\ Jl. Jend. Besar A. H. Nasution No. 1 B Medan \\ ${ }^{2} J u r u s a n$ Hama dan Penyakit Tumbuhan, Fakultas Pertanian, Universitas Brawijaya \\ Jl. Veteran, Malang 65145 \\ ${ }^{3}$ Departemen Proteksi Tanaman, Fakultas Pertanian, Institut Pertanian Bogor \\ Jl. Kamper, Kampus IPB Dramaga, Bogor, 16680 \\ Email: ev_ulina@yahoo.com
}

\begin{abstract}
Lepidopteran community and its parasitoid on cucumber field in Bogor, Sukabumi and Cianjur District, West Java. Cucumber is one of horticultural commodities that are widely cultivated in Indonesia, but information related to Lepidoptera pests and their parasitoids are limited. The aim of this study was to obtain information about Lepidopteran community on cucumber and their parasitoid diversity. Lepidopteran larvae were collected from 16 cucumber sites in the District of Bogor, Sukabumi and Cianjur in November 2014 until May 2015. Larvae were collected from each cucumber plant follow along $60 \mathrm{~m}$ transects. Larvae were collected from the field then brought to the laboratory. All larvae were then reared on cucumber leaves until pupation and parasitoids emerged. The data obtained were tested by analysis of the mean and analysis of variance (One way ANOVA) using the program R Stat. The results showed that cucumber plants were attacked by six species (morphospecies) belonging to four families of Lepidoptera. Diaphania indica (Saunders) (Lepidoptera: Crambidae) is the most abundant species found. All species (morphospecies) of Lepidoptera are more common when the cucumber plants are in the generative growth stage. Our result further showed that $D$. indica was attacked by 9 parasitoid larvae and 3 parasitoid pupae, $C$. chalcites (Lepidoptera: Noctuidae) by 5 parasitoids dan S. litura (Lepidoptera: Noctuidae) by 2 parasitoids. A braconid, Apanteles taragamae, is the most common parasitoid of $D$. indica found in the field. Its parasitism rate can reach $27 \%$ in the field. Overall, this research revealed that a number of parasitoids, that were found attacking Lepidopteran on cucumber indicates their potential use as biological control agents in this agroecosystems.
\end{abstract}

Key words: cucumber, Lepidoptera, parasitoid, pest

\begin{abstract}
ABSTRAK
Komunitas Lepidoptera dan parasitoidnya pada pertanaman mentimun di Bogor, Sukabumi dan Cianjur, Jawa Barat. Mentimun merupakan salah satu komoditas hortikultura yang banyak dibudidayakan di Indonesia, tetapi informasi terkait komunitas hama Lepidoptera serta parasitoidnya masih sangat terbatas. Penelitian ini dilaksanakan untuk mendapatkan informasi tentang struktur komunitas Lepidoptera yang berasosiasi dengan tanaman mentimun, keanekaragaman dan tingkat parasitisasi musuh alaminya. Larva Lepidoptera dikoleksi dari 16 lokasi pertanaman mentimun yang berada di Kabupaten dan Kota Bogor, Sukabumi dan Cianjur pada bulan November 2014 sampai dengan Mei 2016. Larva dikoleksi dari setiap tanaman mentimun mengikuti jalur transek sepanjang $60 \mathrm{~m}$. Larva yang dikoleksi selanjutnya dibawa ke laboratorium untuk dipelihara dan diamati parasitoid yang muncul. Data yang diperoleh diuji dengan analisis nilai tengah dan analisis ragam (One way ANOVA) menggunakan program R Stat. Hasil penelitian menunjukkan bahwa tanaman mentimun diserang oleh enam spesies (morfospesies) hama Lepidoptera yang berasal dari empat famili. Diaphania indica (Saunders) (Lepidoptera: Crambidae) merupakan spesies yang paling banyak ditemukan. Semua spesies hama Lepidoptera lebih banyak ditemukan pada saat tanaman mentimun berada pada stadia pertumbuhan generatif. Hasil penelitian menunjukkan bahwa $D$. indica diserang oleh 9 parasitoid larva dan 3 parasitoid pupa, C. chalcites (Lepidoptera: Noctuidae) oleh 5 parasitoid dan S. litura (Lepidoptera: Noctuidae) oleh 2 parasitoid. Apanteles taragamae merupakan parasitoid $D$. indica yang paling banyak ditemukan di lapangan. Tingkat parasitisasi parasitoid ini di lapang dapat mencapai $27 \%$. Secara keseluruhan hasil penelitian ini menunjukkan bahwa sejumlah parasitoid ditemukan menyerang hama Lepidoptera pada pertanaman mentimun, hal ini menunjukkan potensi parasitoid tersebut sebagai agensia pengendalian hayati di agroekosistem ini.
\end{abstract}

Kata kunci: hama, Lepidoptera, mentimun, parasitoid 


\section{PENDAHULUAN}

Mentimun (Cucumis sativus L.) merupakan salah satu komoditas hortikultura komersial yang dibudidayakan hampir di seluruh wilayah Indonesia mulai dari dataran rendah hingga sedang. Pada tahun 2013, luas areal panen mentimun mencapai 49.296 ha dengan produksi 491.636 ton dan rata-rata hasil 9,97 t/ha (Kementerian Pertanian, 2015). Luas areal panen dan produksi mentimun tersebut jauh lebih rendah dibandingkan lima tahun yang lalu. Penurunan luas lahan tersebut disebabkan oleh perubahan komoditas yang ditanam oleh petani atau konversi lahan pertanian menjadi nonpertanian. Sedangkan angka rata-rata hasil 9,97 t/ha tergolong belum optimal, karena menurut hasil penelitian AVNET (Asean Vegetable Network) potensi hasil mentimun berkisar antara $12-19 \mathrm{t} / \mathrm{ha}$ (Sumpena $\&$ Permadi, 2005) dan potensi hasil 3 varietas mentimun yang dihasilkan oleh Balai Penelitian Tanaman Sayuran berkisar antara 21 - 35 t/ha (Sumpena \& Permadi, 1999). Rendahnya produktivitas tanaman mentimun di tingkat petani disebabkan beberapa faktor seperti ketidaksesuaian lingkungan, teknologi budidaya yang tidak tepat atau serangan organisme pengganggu tanaman.

Sejumlah spesies serangga dan patogen telah dilaporkan menyerang tanaman mentimun di Indonesia mulai dari stadia vegetatif hingga generatif (Prabowo, 2009), namun serangga Lepidoptera yang ditemukan hanya satu spesies dengan kerapatan kurang dari satu ekor per tanaman. Padahal menurut Brown (2015), Diaphania indica Saunders (Lepidoptera: Crambidae) merupakan hama yang umum ditemukan menyerang tanaman famili Cucurbitaceae. Spesies ini tersebar di Pakistan, India, Jepang, Kepulauan Pasifik, Australia, Afrika dan Amerika Selatan (Peter \& David, 1991a; Capinera, 2001). Lebih lanjut Thamrin \& Asikin (2006) melaporkan $D$. indica dapat menimbulkan kerusakan sebesar $80-100 \%$ pada tanaman pare di lahan rawa pasang surut Indonesia.

Di Indonesia, tanaman mentimun saat ini tidak hanya ditanam pada dataran tinggi dan lahan rawa pasang surut tetapi sudah ditanam pada daerah dataran rendah dan sedang. Namun, informasi terkait keberadaan serangga hama Lepidoptera pada tanaman mentimun di Indonesia sangat terbatas. Kabupaten Bogor, Sukabumi dan Cianjur merupakan salah satu sentra pertanaman mentimun di daerah Jawa Barat dan lokasi tersebut dapat dianggap mewakili daerah dataran rendah dan dataran tinggi.

Penelitian ini dilaksanakan untuk mendapatkan informasi tentang struktur komunitas serangga
Lepidoptera yang berasosiasi dengan tanaman mentimun serta keberadaan musuh alaminya di lapang.

\section{METODE PENELITIAN}

Tempat dan Waktu. Pengambilan contoh serangga dilakukan di 16 areal pertanaman mentimun yang ada di Kabupaten Bogor, Sukabumi dan Cianjur Jawa Barat mulai bulan November 2014 sampai Mei 2015 (Tabel 1). Pemeliharaan dan identifikasi contoh serangga dilakukan di Laboratorium Pengendalian Hayati, Departemen Proteksi Tanaman, Fakultas Pertanian, Institut Pertanian Bogor.

Pengambilan Sampel Serangga. Pengambilan sampel serangga dilakukan pada saat tanaman mentimun berada pada stadia vegetatif (umur 2 dan 3 minggu) serta stadia generatif (umur 5, 6 dan 7 minggu). Pengambilan sampel serangga dilakukan pada jalur transek sepanjang $60 \mathrm{~m}$. Sampel serangga diambil langsung dengan tangan dari tanaman yang berada di kanan dan kiri jalur transek tersebut (jumlah tanaman sampel 200 tanaman per lokasi). Jenis serangga yang diambil pada penelitian ini adalah larva serangga Lepidoptera. Masing-masing individu larva tersebut disimpan dalam satu wadah plastik bertutup (diameter $6,5 \mathrm{~cm}$ dan tinggi $10 \mathrm{~cm}$ ), diberi pakan daun mentimun dan diberi label seperti: tanggal sampling, lokasi sampling, umur tanaman dan nomor tanaman. Serangga kemudian dibawa ke laboratorium untuk dipelihara dan dihitung tingkat parasitisasinya.

Pemeliharaan Sampel Serangga. Larva Lepidoptera yang dikoleksi dari lapangan dipelihara di laboratorium (Suhu $28,4^{\circ} \mathrm{C}$, kelembaban $63 \%$ ) dan diberi pakan daun mentimun segar. Larva tersebut dipelihara dalam wadah plastik bertutup (diameter $6,5 \mathrm{~cm}$ dan tinggi $10 \mathrm{~cm}$ ) dan di dalam setiap wadah plastik tersebut dipelihara satu larva. Setiap hari pakan dan wadah plastik tempat pemeliharaan diganti dengan yang baru. Larva yang telah memasuki masa pupa dipisahkan hingga imago muncul. Larva terparasit dipisahkan dan diamati secara intensif hingga imago parasitoid muncul. Parasitoid yang muncul kemudian disimpan dalam alkohol $70 \%$.

Identifikasi Serangga. Identifikasi serangga Lepidoptera dilakukan pada saat stadia larva dan imago. Semua proses identifikasi dilakukan dengan menggunakan buku panduan The Insects of Australia: Lepidoptera (Nielsen \& Common, 1991) dan Key to Selected Pyraloidea (Lepidoptera) Larvae Intercepted at US Ports of Entry: Revision of Pyraloidea in "Keys to some Frequently Intercepted 
Tabel 1. Lokasi administrasi serta lokasi geografi pengambilan contoh serangga

\begin{tabular}{|c|c|c|c|c|}
\hline No & Lokasi administrasi & Koordinat Lokasi & $\begin{array}{l}\text { Ketinggian } \\
(\mathrm{m} \mathrm{dpl})\end{array}$ & $\begin{array}{l}\text { Kelompok } \\
\text { ketinggian }\end{array}$ \\
\hline & Kota Bogor & & & \\
\hline \multirow[t]{2}{*}{1} & Ds. Situgede & $06^{\circ} 32^{\prime} 59,8^{\prime \prime} \mathrm{LS} ; 106^{\circ} 44^{\prime} 39,5^{\prime \prime} \mathrm{BT}$ & 190 & Rendah \\
\hline & Kabupaten Bogor & & & \\
\hline 2 & Ds. Petir, Kec. Dramaga & $06^{\circ} 37^{\prime} 58,6^{\prime \prime} \mathrm{LS} ; 106^{\circ} 43^{\prime} 04,8^{\prime \prime} \mathrm{BT}$ & 482 & Sedang \\
\hline 3 & Ds. Laladon, Kec. Ciomas & $06^{\circ} 34^{\prime} 56,9^{\prime \prime} \mathrm{LS} ; 106^{\circ} 45^{\prime} 04,7^{\prime \prime} \mathrm{BT}$ & 218 & Rendah \\
\hline 4 & Ds. Mekarjaya, Kec. Ciomas & $06^{\circ} 36^{\prime} 44,0^{\prime \prime} \mathrm{LS} ; 106^{\circ} 46^{\prime} 30,5^{\prime \prime} \mathrm{BT}$ & 282 & Rendah \\
\hline 5 & Ds. Cibanteng, Kec. Ciampea & $06^{\circ} 32^{\prime} 54,2^{\prime \prime} \mathrm{LS} ; 106^{\circ} 42^{\prime} 43,0^{\prime \prime} \mathrm{BT}$ & 187 & Rendah \\
\hline 6 & Ds. Cihideung udik, Kec. Ciampea & $06^{\circ} 35^{\prime} 03,8^{\prime \prime} \mathrm{LS} ; 106^{\circ} 43^{\prime} 11,0^{\prime \prime} \mathrm{BT}$ & 239 & Rendah \\
\hline 7 & Ds. Pabuaran, Kec. Kemang & $06^{\circ} 30^{\prime} 01,4^{\prime \prime} \mathrm{LS} ; 106^{\circ} 42^{\prime} 45,8^{\prime \prime} \mathrm{BT}$ & 140 & Rendah \\
\hline \multirow[t]{2}{*}{8} & Ds. Bantarjaya, Kec. Ranca Bungur & $06^{\circ} 32^{\prime} 03,6^{\prime \prime} \mathrm{LS} ; 106^{\circ} 43^{\prime} 35,9^{\prime \prime} \mathrm{BT}$ & 184 & Rendah \\
\hline & Kabupaten Sukabumi & & & \\
\hline 9 & Ds. Karang Tengah, Kec. Cibadak & $06^{\circ} 53^{\prime} 21,8^{\prime \prime} \mathrm{LS} ; 106^{\circ} 48^{\prime} 15,1^{\prime \prime} \mathrm{BT}$ & 464 & Sedang \\
\hline 10 & Ds. Benda, Kec. Cicurug & $06^{\circ} 46^{\prime} 09,9^{\prime \prime} \mathrm{LS} ; 106^{\circ} 49^{\prime} 27,4^{\prime \prime}$ BT & 644 & Sedang \\
\hline \multirow[t]{2}{*}{11} & Ds. Kompa, Kec. Parung Kuda & $06^{\circ} 49^{\prime} 01,9^{\prime \prime} \mathrm{LS} ; 106^{\circ} 45^{\prime} 11,8^{\prime \prime} \mathrm{BT}$ & 458 & Sedang \\
\hline & Kabupaten Cianjur & & & \\
\hline 12 & Ds. Selajambe, Kec. Sukaluyu & $06^{\circ} 48^{\prime} 21,7^{\prime \prime} \mathrm{LS} ; 107^{\circ} 13^{\prime} 57,5^{\prime \prime} \mathrm{BT}$ & 294 & Rendah \\
\hline 13 & Ds. Sindangjaya, Kec. Ciranjang & $06^{\circ} 47^{\prime} 45,9^{\prime \prime} \mathrm{LS} ; 107^{\circ} 16^{\prime} 01,1^{\prime \prime} \mathrm{BT}$ & 274 & Rendah \\
\hline 14 & Ds Bojong, Kec. Karang Tengah & $06^{\circ} 48^{\prime} 15,6^{\prime \prime} \mathrm{LS} ; 107^{\circ} 10^{\prime} 46,5^{\prime \prime} \mathrm{BT}$ & 361 & Sedang \\
\hline 15 & Ds. Jamali, Kec. Mande & $06^{\circ} 44^{\prime} 31,8^{\prime \prime} \mathrm{LS} ; 107^{\circ} 11^{\prime} 32,7^{\prime \prime} \mathrm{BT}$ & 404 & Sedang \\
\hline 16 & Ds. Cikanyere, Kec. Sukaresmi & $06^{\circ} 43^{\prime} 57,2^{\prime \prime} \mathrm{LS} ; 107^{\circ} 05^{\prime} 44,0^{\prime \prime} \mathrm{BT}$ & 797 & Sedang \\
\hline
\end{tabular}

Ds= Desa

Lepidopterous Larvae” by Weisman 1986 (Solis, 1999).

Identifikasi parasitoid diawali dengan menyortir parasitoid tersebut berdasarkan ordo (Hymenoptera atau Diptera). Setelah dipisahkan sesuai ordo kemudian dilanjutkan ke tingkat famili hingga morfospesies. Semua proses identifikasi dilakukan dengan menggunakan buku panduan Hymenoptera of The World (Goulet \& Huber, 1993), Annotated Keys to the Genera of Nearctic Chalcidoidea (Hymenoptera) (Gibson et al., 1997), Manual of the New World Genera of the Family Braconidae (Hymenoptera) (Wharton et al., 1997) dan BOLD Systems Taxonomy Browser.

Analisis Data. Struktur komunitas Lepidoptera pada pertanaman mentimun dianalisis dengan menghitung nilai frekuensi relatif dan dominansi menurut de Sa et al. (2012), yaitu:

$$
D=\frac{1}{S} \quad F r=\frac{n i}{N}
$$

dengan:

$\mathrm{Fr}=$ Frekuensi relatif

$\mathrm{ni}=$ Jumlah individu dari spesies ke-i

$\mathrm{N}=$ Jumlah total individu

$\mathrm{D}=$ Dominansi

$\mathrm{S}=$ Jumlah spesies dalam suatu komunitas

Jika suatu spesies memiliki nilai D > Fr maka spesies tersebut dominan dalam suatu komunitas, dan sebaliknya jika $\mathrm{D}<$ Fr maka spesies tersebut tidak dominan.

Data kelimpahan individu serangga Lepidoptera pada stadia pertumbuhan vegetatif dan generatif tanaman mentimun dan kerapatan individu D.indica di setiap umur tanaman dianalisis dengan sidik ragam (ANOVA) dengan uji $t$ test pada kepercayaan 95\%, sedangkan dinamika populasi $D$. indica dan $D$. indica terparasit dianalisis dengan GLM (General Linear Models) menggunakan software R Stat versi 3.1.3 (R Development Core Team, 2015).

Tingkat parasitisasi parasitoid dihitung dengan rumus yang dimodifikasi dari Hamid et al. (2003) yaitu: 


$$
\% \text { parasitasi }=\frac{\sum \text { larva terparasit }}{\sum \text { total larva terkoleksi }} \times 100 \%
$$

\section{HASIL DAN PEMBAHASAN}

\section{Serangga Lepidoptera pada Pertanaman}

Mentimun. Secara keseluruhan jumlah serangga Lepidoptera yang telah dikumpulkan dari 16 lokasi penelitian adalah 6.510 individu yang terdiri dari 4 famili dan 6 spesies (Tabel 2). Noctuidae merupakan famili yang anggota spesiesnya banyak menyerang tanaman mentimun tetapi dari total jumlah individu, Crambidae merupakan famili Lepidoptera yang paling dominan berasosiasi dengan tanaman mentimun. Famili Noctuidae terdiri dari 3 spesies yaitu Chrysodeixis chalcites, Spodoptera litura dan Anadevidia Sp. Larva $C$. chalcites berwarna hijau pucat dengan garis memanjang pada bagian lateral (Gambar 1A), sedangkan imago memiliki sayap depan berwarna coklat dengan dua spot oval berwarna perak dan pada saat istirahat sayap dilipat atas tubuh sehingga berbentuk seperti tenda (Gambar
1B). Larva S. litura memiliki variasi warna mulai hijau pucat, hijau tua sampai coklat dengan garis kuning cerah di sepanjang tubuhnya (Gambar 2A), sedangkan imago memiliki sayap depan berwarna coklat kemerahan dengan garis-garis berwarna coklat muda (pucat) membentuk pola yang kompleks sepanjang vena (Gambar 2B). Larva instar awal Anadevidia sp. berwarna hijau dengan duri hitam dan beberapa proleg hilang sehingga larva bergerak seperti ulat jengkal (Gambar 3A) sedangkan pada instar akhir duri menjadi putih (Gambar 3B). Larva $D$. indica. berwarna hijau dengan dua garis pucat di sepanjang sisi dorsal (Gambar 4A), sedangkan imago memiliki sayap depan transparan dengan bagian pinggir berwarna coklat gelap, dan memiliki embelan berupa seberkas rambut berwarna cokelat pada bagian ujung abdomen (Gambar 4B). Larva Hesperiidae01 berwarna hijau dengan serangkaian garisgaris gelap dan pucat di sepanjang tubuh, kepala berwarna hitam, masing-masing larva hidup dalam gulungan daun yang direkatkan dengan benang sutra (Gambar 5A). Larva Geometridae01 tidak memiliki proleg yang lengkap, hanya dua atau tiga pasang pada

Tabe1 2. Serangga Lepidoptera yang berasosiasi dengan tanaman mentimun, jumlah individu dan kategori dominasi

\begin{tabular}{|c|c|c|c|c|c|c|c|}
\hline Famili & $\begin{array}{c}\text { Spesies/ } \\
\text { morfospesies }\end{array}$ & ni & $\mathrm{n}$ & $\begin{array}{c}\text { Rataan jumlah individu } \\
\pm \text { simpangan baku }\end{array}$ & $\mathrm{Fr}$ & Nilai D & $\mathrm{D}$ \\
\hline Crambidae & D. indica & 5.072 & 16 & $317,00 \pm 243,61$ & 0,779 & 0,17 & $\mathrm{~d}$ \\
\hline Noctuidae & C. chalcites & 678 & 16 & $42,38 \pm 62,07$ & 0,104 & 0,17 & nd \\
\hline Noctuidae & Anadevidia $\mathrm{sp}$ & 12 & 3 & $4,00 \pm 5,86$ & 0,002 & 0,17 & nd \\
\hline Noctuidae & S. litura & 674 & 13 & $51,85 \pm 97,12$ & 0,104 & 0,17 & nd \\
\hline Hesperiidae & Hesperiidae01 & 70 & 11 & $6,36 \pm 4,03$ & 0,011 & 0,17 & nd \\
\hline Geometridae & Geometridae01 & 4 & 3 & $1,33 \pm 0,58$ & 0,001 & 0,17 & nd \\
\hline Total individu & & 6.510 & & & & & \\
\hline
\end{tabular}

$\mathrm{ni}=$ total individu; $\mathrm{n}=$ jumlah lokasi; $\mathrm{Fr}=$ frekuensi relatif; $\mathrm{D}=1$ /seluruh spesies (dominansi) (de Sa et al., 2012); Fr $>D$ (d/dominan); Fr $<D$ (nd/non dominan).
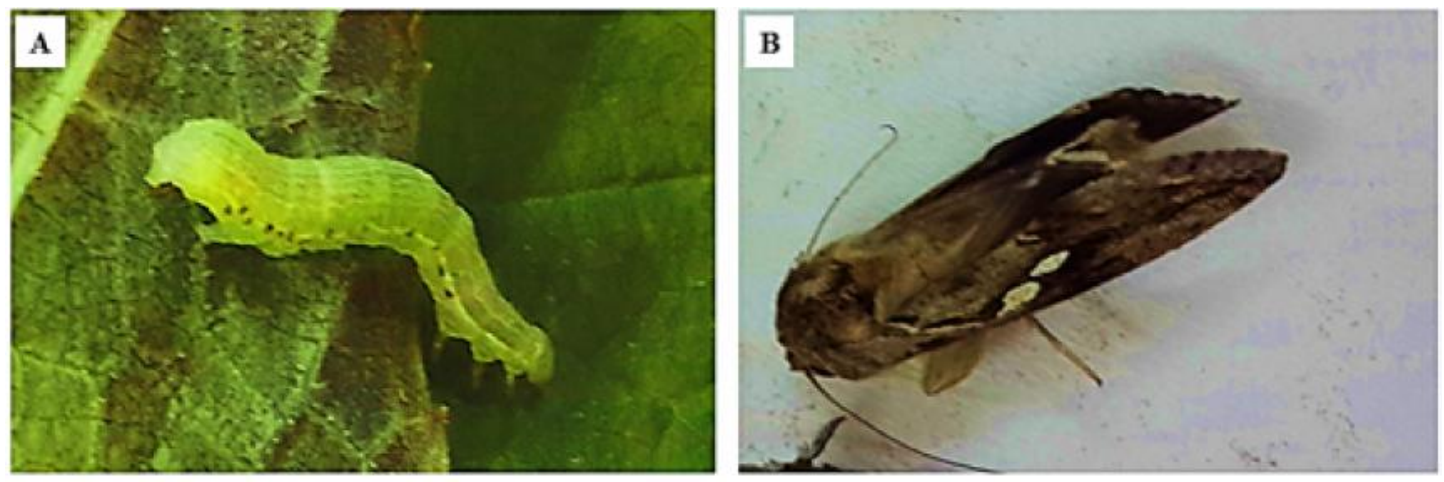

Gambar 1. Chrysodeixis chalcites (A) larva dan (B) imago 

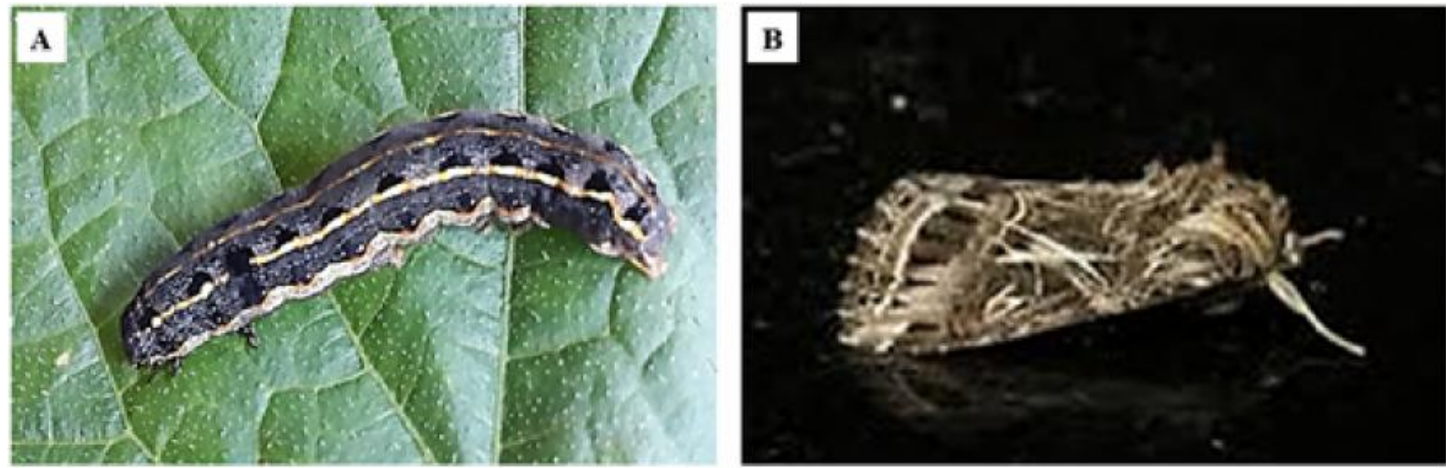

Gambar 2. Spodoptera litura (A) larva dan (B) imago
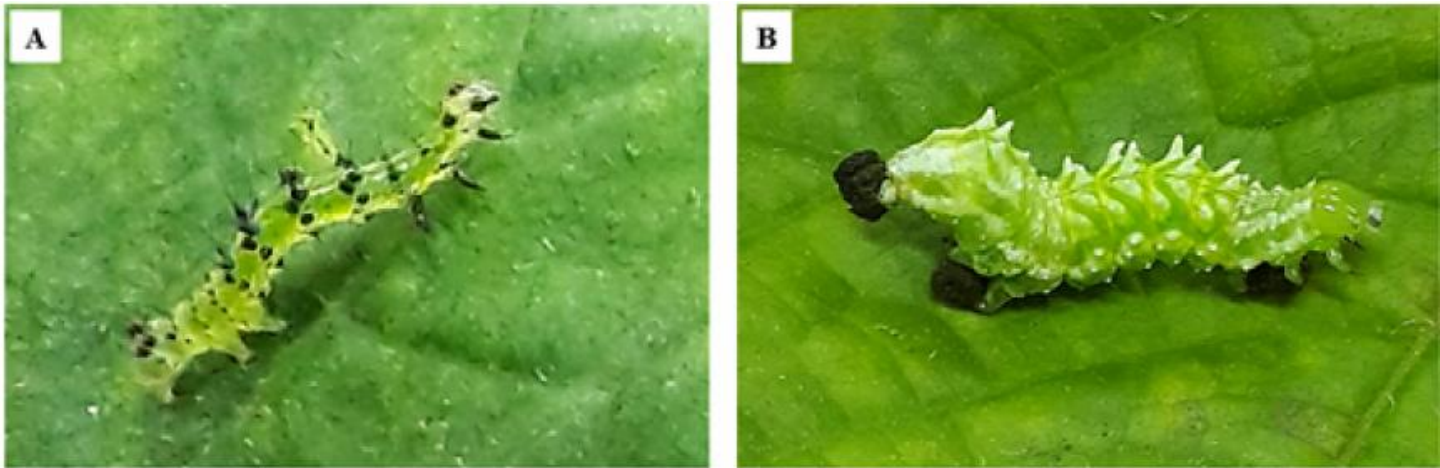

Gambar 3. Anadevidia sp. (A) larva instar awal dan (B) larva instar akhir
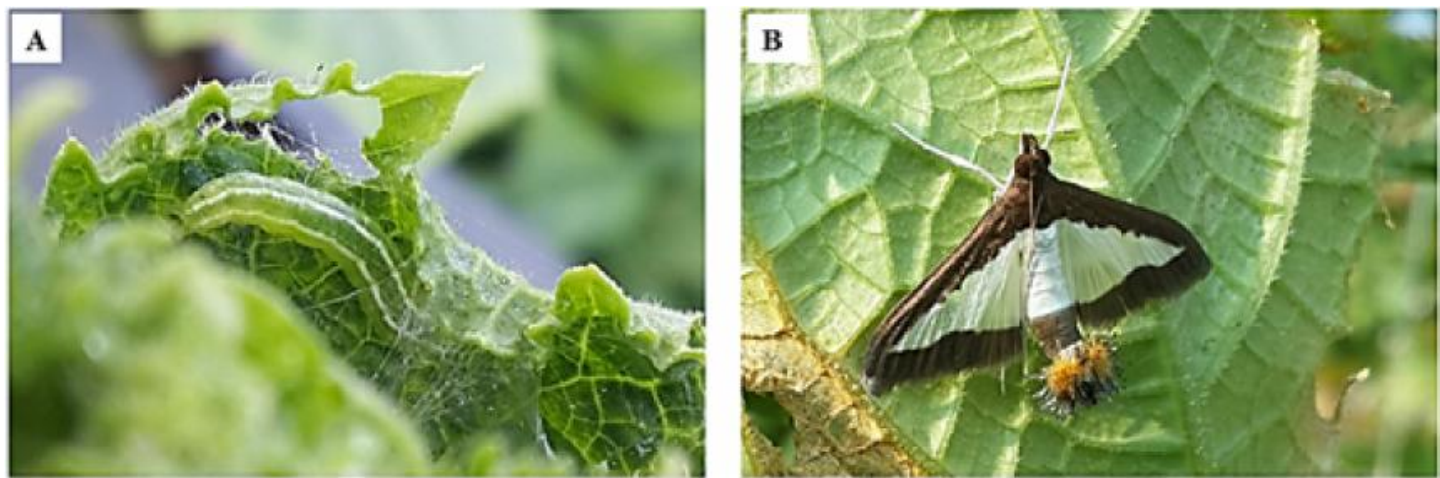

Gambar 4. Diaphania indica (A) larva dan (B) imago
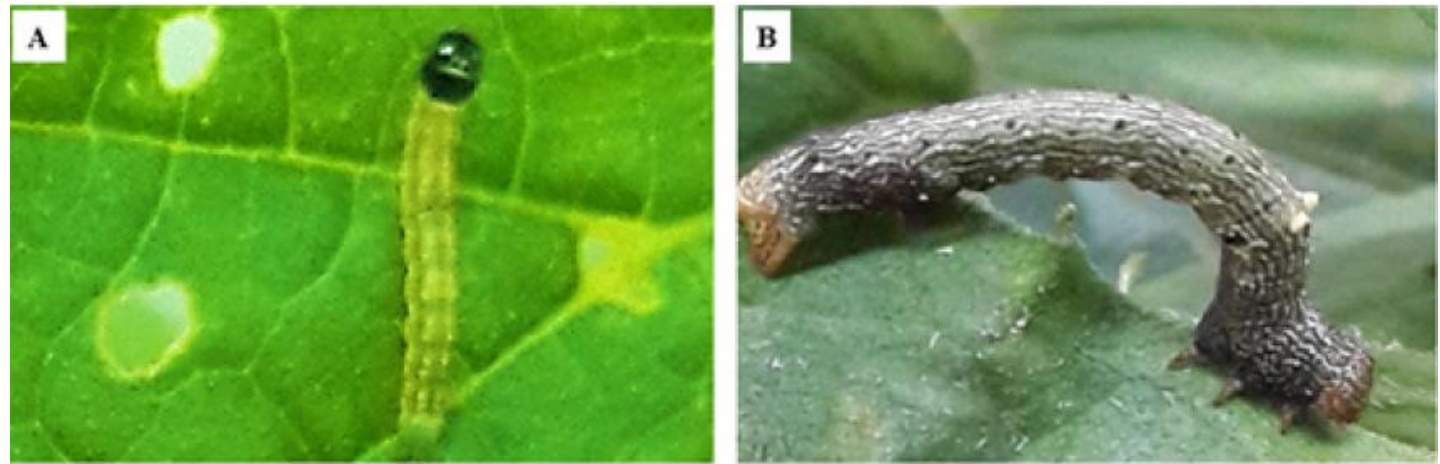

Gambar 5. Larva (A) Hesperiidae01 dan (B) Geometridae01 
akhir posterior dan dilengkapi dengan pelengkap di ujung tubuh (Gambar 5B).

Diaphania indica merupakan serangga Lepidoptera yang ditemukan di semua lokasi penelitian dengan rata-rata kelimpahan 317 individu per lokasi (Tabel 2) dengan rata-rata kerapatan berkisar antara 1,00 hingga 2,20 individu per tanaman (Gambar 6). Namun, hal ini bertentangan dengan penelitian yang
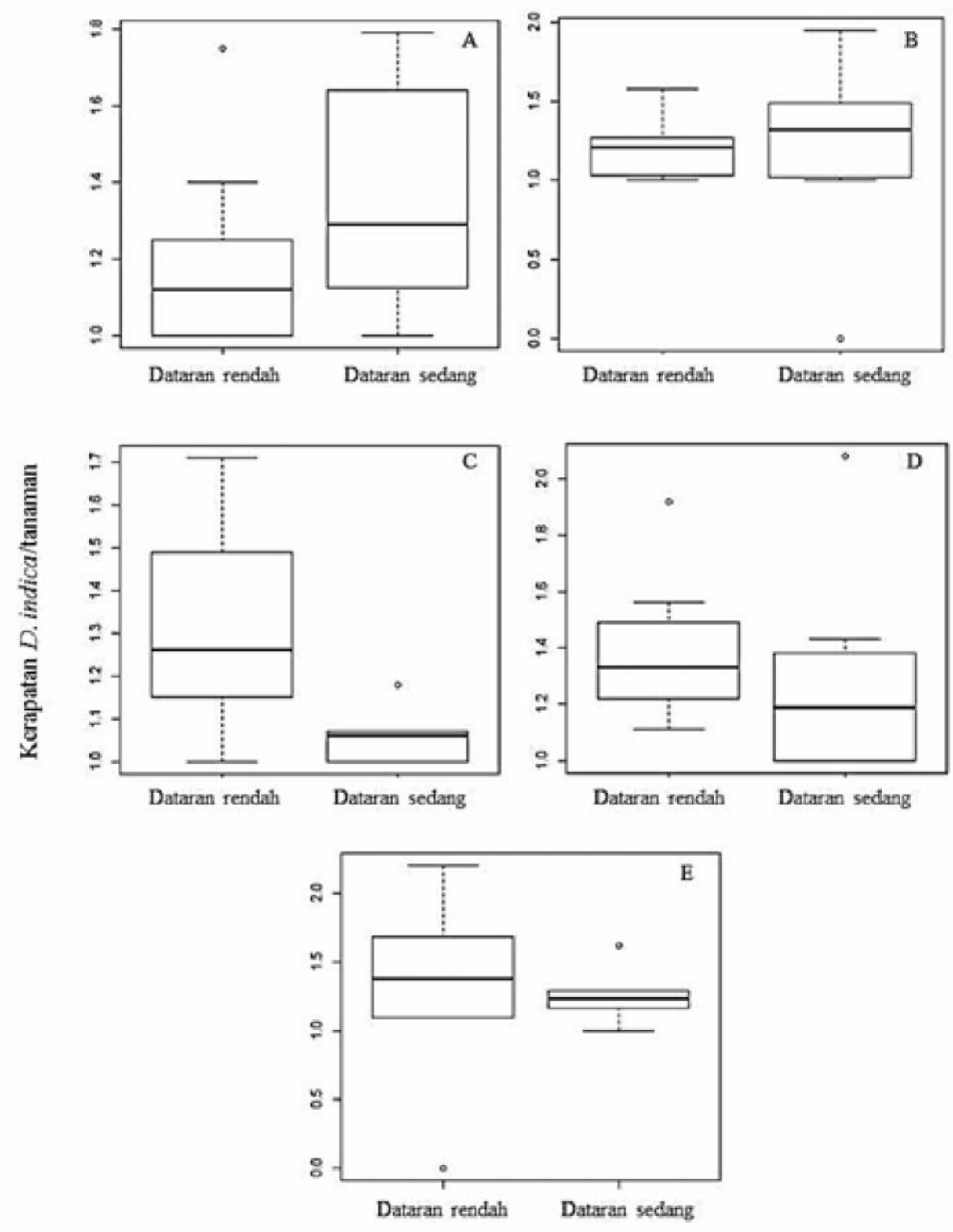

Ketinggian lokasi pertanaman mentimun

Gambar 6. Boxplot kerapatan larva D. indica per tanaman pada tanaman mentimun umur (A) 2 minggu (Dataran rendah $($ median $=1,12 ; \min =1 ;$ maks $=1,75 ;$ galat baku $=0,08)$, Dataran sedang $($ median $=1,29 ;$ min $=1 ;$ maks $=1,79 ;$ galat baku $=0,12)),(\mathrm{B}) 3$ minggu $($ Dataran rendah $($ median $=1,21 ; \min =1 ;$ maks $=$ 1,58; galat baku $=0,07)$, Dataran sedang $($ median $=1,32 ; \min =0 ;$ maks $=1,95 ;$ galat baku $=0,23)),(\mathrm{C})$ 5 minggu (Dataran rendah (median $=1,26 ; \min =1 ;$ maks $=1,71$; galat baku $=0,08$ ), Dataran sedang $($ median $=1,06 ; \min =1 ;$ maks $=1,18 ;$ galat baku $=0,02)),($ D) 6 minggu $($ Dataran rendah $($ median $=$ $1,33 ; \min =1,11 ;$ maks $=1,92 ;$ galat baku $=0,08)$, Dataran sedang $($ median $=1,19 ; \min =1 ;$ maks $=$ 2,08; galat baku $=0,15)$ ), dan $(\mathrm{E}) 7$ minggu (Dataran rendah $($ median $=1,41 ; \min =1,09 ;$ maks $=2,2$; galat baku $=0,15)$, Dataran sedang (median $=1,23 ; \min =1 ;$ maks $=1,62 ;$ galat baku $=0,07)$ ) yang ditanam pada dataran rendah dan sedang 
dilakukan oleh Prabowo (2009), yang melaporkan bahwa serangga Lepidoptera yang berasosiasi dengan tanaman mentimun hanya $D$. indica dan serangga ini ditemukan dengan kerapatan $<1$ ekor per tanaman. Perbedaan ini diduga dapat terjadi karena beberapa hal, antara lain adalah adanya perbedaan ketinggian lokasi penelitian. Hama D. indica dengan jumlah 5.072 individu ditemukan pada daerah dengan ketinggian antara 190 797 m dpl sedangkan keberadaan $D$. indica dengan kerapatan $<1$ ekor per tanaman ditemukan pada daerah dengan ketinggian $1.100 \mathrm{~m}$ dpl. Data pada Gambar 7 menunjukkan bahwa ketinggian lokasi penanaman mentimun mempengaruhi kelimpahan hama $D$. indica. Tanaman mentimun yang ditanam pada dataran rendah (<300 mdpl) lebih banyak diinfestasi oleh $D$. indica dibandingkan dengan tanaman mentimun yang ditanam pada dataran sedang $(300-800 \mathrm{~m} \mathrm{dpl})(\mathrm{F}=5,05 ; \mathrm{P}=$ 0,04). Menurut Savopoulou et al. (2012), kelimpahan dan sebaran serangga turut dipengaruhi oleh suhu dan kelembaban. Lebih lanjut Okonya \& Kroschel (2013) menjelaskan bahwa suhu berkaitan erat dengan ketinggian suatu tempat. Selain itu, kekayaan spesies serangga pada suatu lokasi turut dipengaruhi oleh perbedaan budidaya tanaman antarpetani (Nugraha et
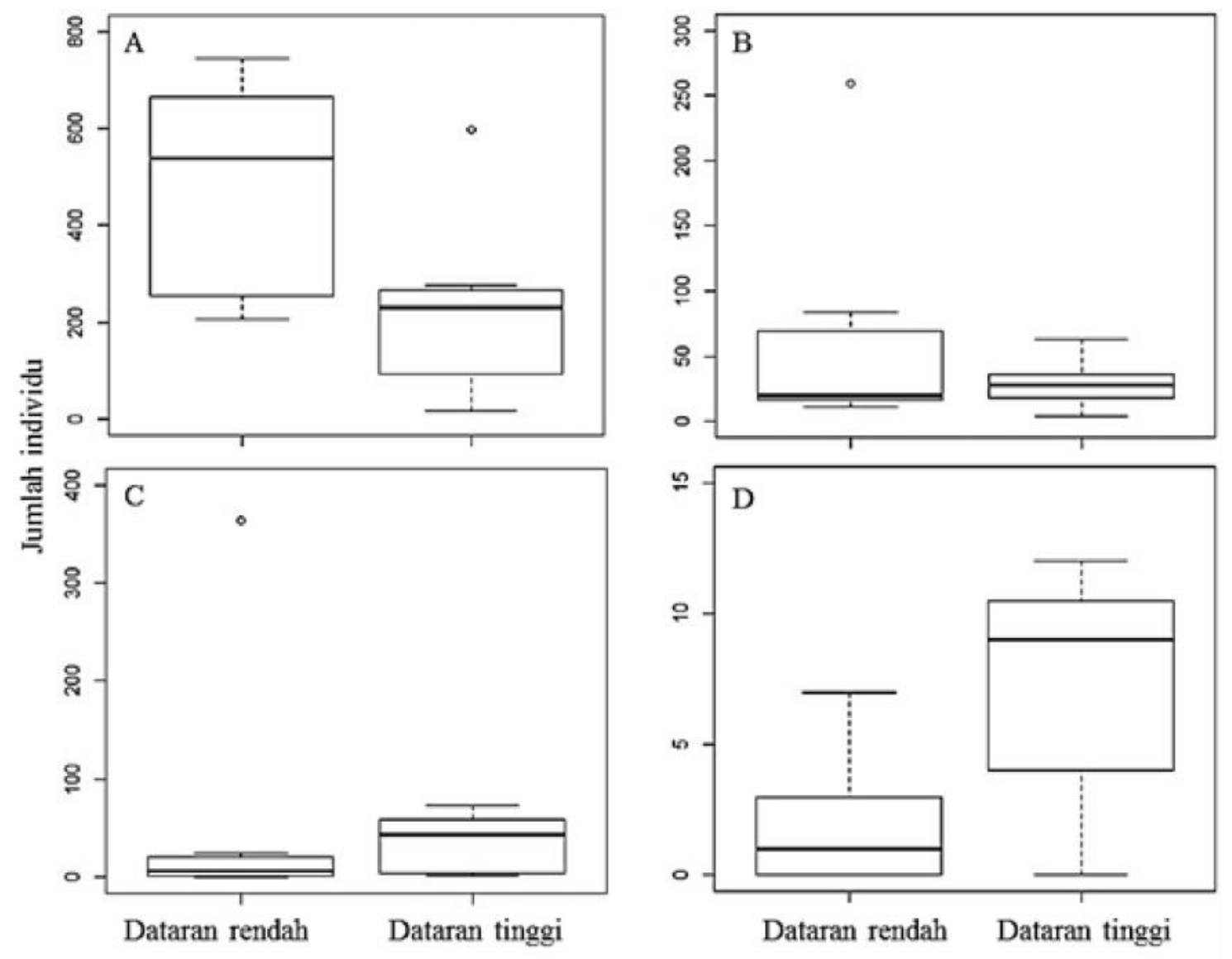

Ketinggian lokasi pertanaman mentimun

Gambar 7. Boxplot kelimpahan individu (A) D. indica $($ Dataran rendah $($ median $=537 ; \min =207 ;$ maks $=744$; galat baku $=87,27)$, Dataran sedang $($ median $=231 ; \min =17 ;$ maks $=598 ;$ galat baku $=73,24)),(B)$ C. chalcites $($ Dataran rendah $($ median $=20 ; \min =11 ;$ maks $=259$; galat baku $=33,75)$, Dataran sedang $($ median $=28 ; \min =4 ;$ maks $=63 ;$ galat baku $=7,29)$ ), (C) $S$. litura $($ Dataran rendah $($ median $=6 ;$ min $=0 ;$ maks $=364 ;$ galat baku $=50,88)$, Dataran sedang $($ median $=44 ; \min =1 ;$ maks $=74 ;$ galat baku $=11,9)$ ) dan $($ D) Hesperidae01 $($ Dataran rendah $($ median $=1 ; \min =0 ;$ maks $=7$; galat baku $=$ $1,07)$, Dataran sedang (median $=9 ;$ min $=0 ;$ maks $=12$; galat baku $=1,82)$ ) pada tanaman mentimun yang ditanam pada dataran rendah dan dataran sedang 
al., 2014) serta perbedaan kompleksitas lanskap (Zhao et al., 2014).

Rata-rata jumlah individu serangga Lepidoptera yang ditemukan pada stadia pertumbuhan generatif tanaman mentimun lebih banyak dibandingkan saat tanaman berada pada stadia vegetatif (Gambar 8). Pada stadia pertumbuhan tanaman mentimun yang berbeda, ditemukan perbedaan komposisi serangga Lepidoptera. Pada stadia vegetatif ditemukan empat spesies serangga, yaitu $D$. indica, $C$. chalcites, $S$. litura dan Hesperidae01 sedangkan pada stadia pertumbuhan generatif ditemukan enam spesies serangga Lepidoptera, yaitu $D$. indica,
C. chalcites, S. litura, Anadevidia sp, Geometridae01 dan Hesperiidae01. Serangga Lepidoptera yang paling banyak ditemukan berasosiasi dengan tanaman mentimun baik pada stadia pertumbuhan vegetatif maupun generatif adalah $D$. indica (Tabel 3). Vanisree et al. (2005) juga melaporkan bahwa serangan tertinggi hama $D$. indica terjadi saat tanaman mentimun berada pada stadia generatif. Kelimpahan populasi serangga yang tinggi pada saat tanaman berada pada stadia generatif disebabkan serangga sudah beradaptasi dan berkembang pada pertanaman tersebut. Fitriyana (2015) menjelaskan bahwa $D$. indica mampu menyelesaikan

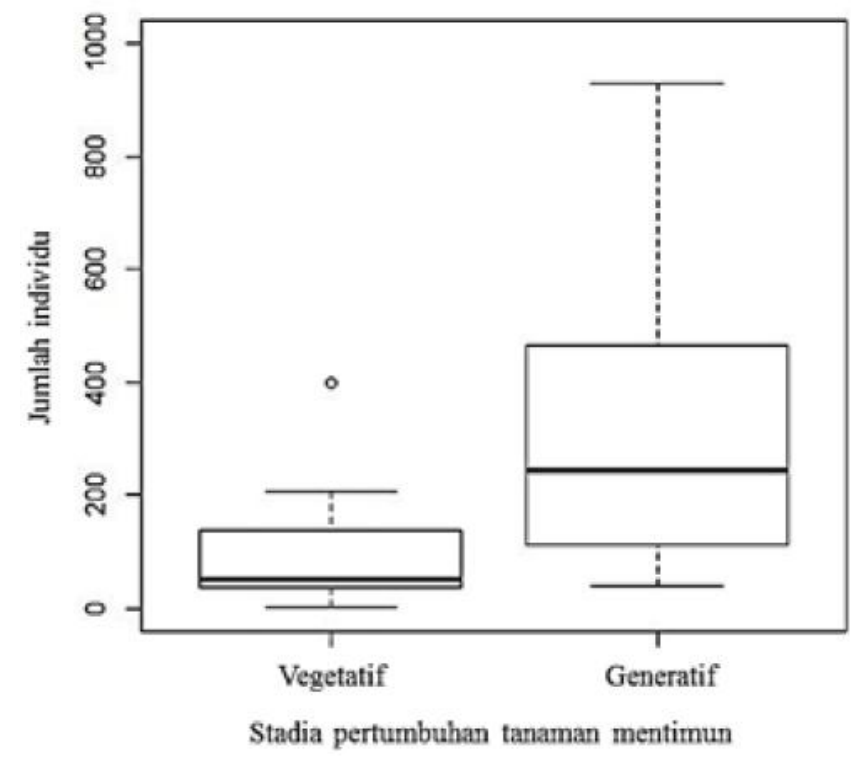

Gambar 8. Boxplot jumlah individu serangga Lepidoptera pada stadia pertumbuhan vegetatif $($ median $=51,5 ; \min =$ 3 ; maks $=400$; galat baku $=25,7)$ dan generatif $($ median $=243 ; \min =39 ;$ maks $=928$; galat baku $=$ 64,56) tanaman mentimun di 16 lokasi pertanaman mentimun

Tabel 3. Jumlah individu serangga Lepidoptera pada stadia pertumbuhan vegetatif dan generatif tanaman mentimun

\begin{tabular}{lccc}
\hline Species/morfospesies & Vegetatif $^{1}$ & Generatif $^{1}$ & Statistik $^{2}$ \\
\hline D. indica & $89,56 \pm 102,51$ & $227,44 \pm 205,10$ & $F_{(1.30)}=5,79 ; P=0,02^{*}$ \\
C. chalcites $^{*}$ Anadevidia sp & $3,00 \pm 3,03$ & $39,38 \pm 61,95$ & $F_{(1.30)}=5,50 ; P=0,03^{*}$ \\
S. litura & $0,00 \pm 0,00$ & $0,75 \pm 2,08$ & $F_{(1.30)}=2,08 ; P=0,16^{\text {th }}$ \\
Hesperiidae01 & $5,19 \pm 9,54$ & $36,94 \pm 83,66$ & $F_{(1.30)}=2,28 ; P=0,42^{\text {tn }}$ \\
Geometridae01 & $0,56 \pm 1,03$ & $3,81 \pm 4,21$ & $F_{(1.30)}=8,98 ; P=0,01^{* *}$ \\
\hline Total individu & $0,00 \pm 0,00$ & $0,25 \pm 0,58$ & $F_{(1.30)}=3,00 ; P=0,09^{\text {th }}$ \\
\hline
\end{tabular}

${ }^{1}$ Rata-rata \pm simpangan baku; ${ }^{2}$ Beda nyata kemelimpahan spesies/morfospesies serangga Lepidoptera antar stadia pertumbuhan tanaman mentimun berdasarkan uji ANOVA. tn $=$ tidak nyata; $*$ = beda nyata pada taraf $5 \% ; * *$ = beda nyata pada taraf $1 \%$. 
siklus hidupnya dalam kurun waktu 26 hari. Sedangkan siklus hidup $D$. indica di India adalah 23,4 hari (Peter \& David, 1992), di Jepang adalah 18,2 hari (Kinjo \& Arakaki, 2002) dan di Iran adalah 19,91 hari (Hosseinzade et al., 2014). Walaupun siklus hidup serangga bervariasi menurut ras geografis, tanaman inang dan kondisi laboratorium (Hosseinzade et al., 2014) namun siklus hidup $D$. indica tersebut menunjukkan bahwa pada saat tanaman mentimun berada pada stadia generatif, $D$. indica telah memasuki generasi kedua.

Keanekaragaman serangga Lepidoptera yang tinggi pada stadia pertumbuhan generatif tanaman mentimun dapat dikaitkan dengan fenologi dan arsitektur tanaman. Pada stadia generatif, tanaman memiliki jumlah daun lebih banyak dan tumpang tindih sehingga pakan tersedia dalam jumlah berlimpah dan juga memudahkan pergerakan larva dari satu tanaman ke tanaman lainnya. Lawton (1983) menjelaskan bahwa arsitektur tanaman yang menyangkut ukuran, bentuk, dan atribut lainnya sangat mempengaruhi keanekaragaman serangga fitofag yang berasosiasi dengan tanaman tersebut.

Parasitoid yang berasosiasi dengan Serangga Lepidoptera pada Tanaman Mentimun. Dari enam spesies serangga Lepidoptera yang ditemukan berasosiasi dengan tanaman mentimun, hanya tiga spesies yang ditemukan terparasit, yaitu $D$. indica, $C$. chalcites dan $S$. litura (Tabel 4). Hama D. indica diparasit oleh 9 parasitoid larva (famili Braconidae, Ichneumonidae dan Lonchaeidae, satu parasitoid larva - pupa (Ichneumonidae) serta dua parasitoid pupa (Chalcididae dan Tachinidae). Hal ini sesuai dengan temuan Peter \& David (1991b) yang melaporkan bahwa D. indica memiliki sejumlah musuh alami, yaitu 13 parasitoid larva, 3 parasitoid pupa, 3 predator dan 1 entomopatogen. Parasitoid telur Trichogramma chilonis, parasitoid larva Dolichogenidea stantoni dan entomopatogen Nomurea rileyii juga dilaporkan berasosiasi dengan $D$. indica (Visalakshy, 2005).

Hasil penelitian menunjukkan bahwa jumlah larva $D$. indica terparasit meningkat sejalan dengan meningkatnya kelimpahan larva $D$. indica (Gambar 9), dimana parasitoid yang dominan adalah $A$. taragamae (Tabel 4). Hal ini menunjukkan bahwa A. taragamae merupakan agensia pengendali hayati yang efektif mengendalikan larva $D$. indica. Menurut Dannon et al. (2010) musuh alami yang memiliki respon positif terhadap peningkatan populasi hama merupakan indikasi agensia pengendali hayati tersebut efektif mengendalikan hama. Lebih lanjut Walde \& Murdoch (1988) menjelaskan bahwa jika laju parasitisme meningkat sejalan dengan meningkatnya kepadatan inang maka musuh alami tersebut berkontribusi terhadap pengaturan populasi inang sehingga terjadi keseimbangan alami.

Hasil temuan penelitian ini menunjukkan bahwa D. indica adalah hama utama pada tanaman mentimun yang mendapat tekanan cukup besar dari musuh alaminya, A. taragame. Total sekitar $27 \%$ dari populasi Diaphania akan mengalami kematian karena diserang parasitoid. Nilai kematian akan lebih tinggi jika ditambah faktor mortalitas karena predator serta patogen. Kondisi ini merupakan indikasi bahwa salah satu penyebab mengapa Diaphania sampai saat ini adalah hama minor di lapang adalah karena musuh alaminya masih cukup efektif mengendalikan populasi inangnya. Secara umum, dapat disimpulkan bahwa implementasi pengendaliah hayati harus menjadi satu kesatuan dalam praktek budidaya mentimun. Sistem budidaya mentimun harus dijalankan dengan prinsip konservasi musuh alami dan tidak mengandalkan pestisida.

\section{SIMPULAN}

Serangga Lepidoptera yang berasosiasi dengan tanaman mentimun terdiri dari empat famili dan enam spesies (morfospesies), yaitu $D$. indica (famili Crambidae), C. chalcites, S. litura dan Anadevidia sp (famili Noctuidae), Geometridae01 dan Hesperiidae01. D. indica merupakan serangga Lepidoptera yang mendominasi tanaman mentimun dan jumlahnya berlimpah pada saat tanaman mentimun berada pada stadia pertumbuhan generatif.

Tiga spesies serangga Lepidoptera yang berasosiasi dengan tanaman mentimun ditemukan memiliki sejumlah parasitoid. D. indica diparasit oleh 12 spesies (morfospesies) parasitoid, C. chalcites diparasit oleh 5 spesies (morfospesies) parasitoid sedangkan $S$. litura diparasit oleh 2 spesies (morfospesies) parasitoid. $A$. taragamae (Hymenoptera: Braconidae) merupakan spesies musuh alami $D$. indica yang mampu memarasit hingga $27 \%$.

\section{SANWACANA}

Terima kasih kepada 16 petani mentimun Jawa Barat yang telah memberikan akses pada pertanaman mentimun milik mereka. Kami berterima kasih kepada S.F. Lizmah, I. Fitriyana, A. Fitri, Susilawati dan I. Lukmana yang telah membantu serangkaian penelitian. Penelitian ini didanai oleh Badan Litbang Pertanian Kementerian Pertanian Republik Indonesia dan Kementerian Riset Teknologi dan Pendidikan Tinggi Republik Indonesia. 


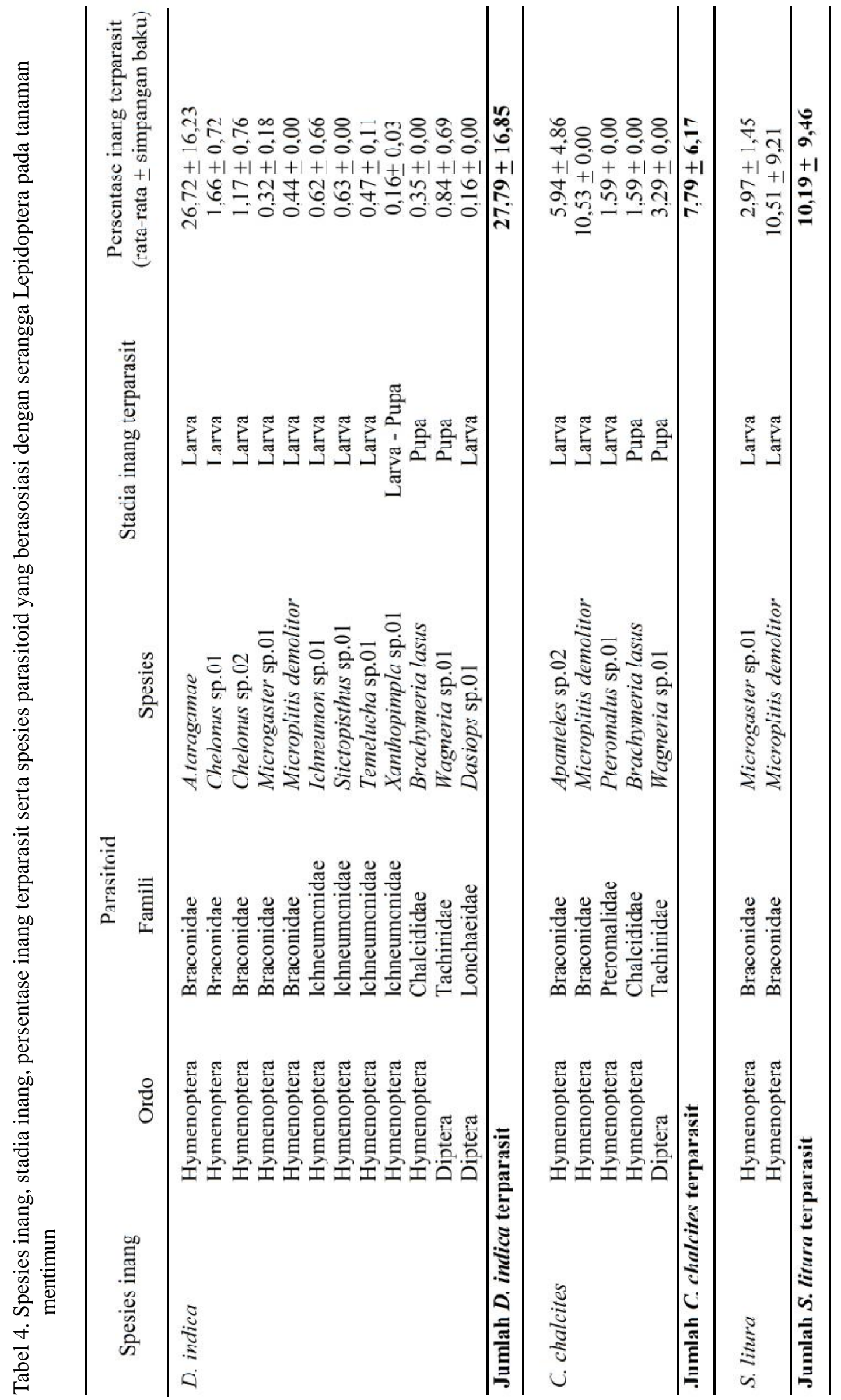




\section{DAFTAR PUSTAKA}

Brown H. 2015. Common Insects Pests of Cucurbits. Agnote no I59. Northern Territory Government, Australia.

Capinera JL. 2001. Handbook of Vegetable Pests. Academic Press, California.

Dannon EA, Tamò M, van Huis A, \& Dicke M. 2010. Functional response and life history parameters of Apanteles taragamae, a larval parasitoid of Maruca vitrata. BioControl 55(3): 363-378.

Fitriyana I. 2015. Statistik Demografi Diaphania indica (Saunders) (Lepidoptera: Crambidae) pada Tanaman Mentimun. [Tesis] IPB, Bogor.

Gibson GAP, Huber JT, \& Woolley JB. 1997. Annotated Keys to the Genera of Nearctic Chalcidoidea (Hymenoptera). NRC Research Press, Ottawa.

Goulet H \& Huber JT. 1993. Hymenoptera of the World: an Identification Guide to Families. Agriculture Canada, Ottawa.

Hamid H, Buchori D, \& Triwidodo H. 2003. Keanekaragaman parasitoid dan parasitisasinya pada pertanaman padi di Kawasan Taman Nasional Gunung Halimun. Hayati 10(3): 85-90.

Hosseinzade S, Izadi H, Namvar P, \& Samih MA. 2014. Biology, temperature thresholds, and degree-day requirements for development of the cucumber moth, Diaphania indica, under laboratory conditions. J. Insect Sci. 14(61): 182-189.

Kementerian Pertanian. 2015. Basis Data Pertanian. http://aplikasi.pertanian.go.id/bdsp/hasil_ind.asp. Diakses tanggal 5 Mei 2015.

Kinjo K \& Arakaki N. 2002. Effect of temperature on development and reproductive characteristics of Diaphania indica (Saunders) (Lepidoptera: Pyralidae). Appl. Entomol. Zool. 37(1): 141-145.

Lawton JH. 1983. Plant architecture and the diversity of phytophagous insects. Annu. Rev. Entomol. 28: 23-39.

Nielsen ES \& Common IFB. 1991. Lepidoptera. In: Naumann ID, Carne PB, Lawrence JF, Nielsen ES, Spradbery JP, Taylor RW, Whitten MJ, \& Littlejohn MJ (Eds.). The Insects of Australia Vol. II $2^{\text {nd }}$ edition. pp. 817-915. Melbourne University Press, Victoria.
Nugraha MN, Buchori D, Nurmansyah A, \& Rizali A. 2014. Interaksi tropik antara hama dan parasitoid pada pertanaman sayuran: faktor pembentuk dan implikasinya terhadap keefektifan parasitoid. JEI 11(2): 103-112.

Okonya JS \& Kroschel J. 2013. Incidence, abundance and damage by the sweet potato butterfly (Acraea acerata Hew.) and the African sweet potato weevils (Cylas spp.) across an altitude gradient in Kabale district, Uganda. J. AgriScience 3(11): 814-824.

Peter C \& David BV. 1991a. Biology of Goniozus sensorius Gordh (Hymenoptera: Bethylidae) a parasitoid of the pumpkin caterpillar, Diaphania indica (Saunders) (Lepidoptera: Pyralidae). Int J. Trop. Insect. Sci. 12(4): 339-345.

Peter C \& David BV. 1991b. Natural enemies of the pumpkin caterpillar Diaphania indica (Lepidoptera: Pyralidae) in Tamil Nadu. Biocontrol 36(3): 391-394.

Peter C \& David BV. 1992. Study on the thermal requirement for development of Diaphania indica. J. Insect Sci. 5(2): 172-174.

Prabowo DP. 2009. Survei hama dan penyakit pada pertanaman mentimun (Cucumis sativus Linn.) di Desa Ciherang, Kecamatan Pacet, Kabupaten Cianjur, Jawa Barat. [Skripsi] IPB, Bogor.

R Development Core Team. 2015. R: A language and environment for statistical computing. Vienna (AT). R Foundation for Statistical Computing. http://www.R-project.org. Diakses tanggal $5 \mathrm{Mei}$ 2015.

de Sa RF, Castellani MA, Ribeiro AEL, Perez-Maluf R, Moreira AA, Nagamoto NS, \& do Nascimento AS. 2012. Faunal analysis of the species Anastrepha in the fruit growing complex Gavião River, Bahia, Brazil. Bull. Insect 65(1): 37-42.

Savopoulou-Soultani SM, Papadopoulos NT, Milonas P, \& Moyal P. 2012. Abiotic Factors and Insect Abundance. Psyche. 2p.

Solis MA. 1999. Key to Selected Pyraloidea (Lepidoptera) Larvae Intercepted at US Ports of Entry: Revision of Pyraloidea in "Keys to some Frequently Intercepted Lepidopterous Larvae" by Weisman 1986. Proceedings of the Entomological Society of Washington 101(3): 645-686. 
Sumpena U \& Permadi AH. 1999. Pelepasan Varietas Visalakshy PNG. 2005. Natural enemies of Diaphania Unggul Mentimun Bersari Bebas Saturnus, indica (Saunders) (Pyralidae: Lepidoptera) in Mars dan Pluto. Badan Litbang Pertanian, Jakarta.

Sumpena U \& Permadi AH. 2005. Cucumber Multi Locations Trial in the Lowland of Indonesia. Asean Vegetable Research and Development Centre, Taiwan.

Thamrin M \& Asikin. 2006. Alternatif pengendalian hama serangga sayuran ramah lingkungan di lahan lebak. In: Noor M, Noor I \& Supriyono A (Eds.). Prosiding Seminar Nasional Pengelolaan Lahan Terpadu. pp. 375-386. Banjarbaru, Indonesia.

Vanisree K, Rajasekhar P, Rao VRS, \& Rao VS. 2005. Karnataka. Entomon 30(3): 261-262.

Walde SJ \& Murdoch WW. 1988. Spatial density dependence in parasitoids. Ann. Rev. Entomol. 33: 441-466.

Wharton RA, Marsh PM, \& Sharkey MJ. 1997. Manual of the New World Genera of the Family Braconidae (Hymenoptera). International Society of Hymenopterists, Washington DC.

Zhao ZH, Hui C, Hardev S, Ouyang F, Dong Z, \& Ge F. 2014. Responses of cereal aphids and their parasitic wasps to landscape complexity. J. Econ. Entomol. 107(2): 630-637. Diaphania indica (Sauders) on cucumber in Krishna - Godavari zone. J. Plant Prot. Environ. 2(1): 127-129. 